\title{
Pengaruh Sudut dan Jari-Jari Saluran Menikung terhadap Konsentrasi Aliran Sedimen Suspensi arah Transversal
}

\section{Effect Of Angle And Radius Of Curved Channel Flows At Concentration Of Suspended Sediment In Transversal Direction}

\author{
Chairul Muharis
}

Jurusan Teknik Sipil Politeknik Negeri Padang Kampus Limau Manis Padang

Telp.0751-72590 Fax.0751-72576 Email: ch_muharis@yahoo.com

\begin{abstract}
The change in channel dimension has a great effect on the flow hydraulic parameters. Likewise, the angle and radius of the bend are not the same will also affect the concentration of suspended sediment flow. To determine the effect of angle and radius of the bend, the measurement of susupended sediment concentration was done at 4 (four) location in Mataram irrigation channel curve. The four locations describe 2 channels having relatively the same angle but having different radius, and 2 (two) channels having the same relative radius but having different angles. Measurement of suspended sediment concentration in tranversal direction is done some depth point used by opcon probe. The results of the research for different angle of bend shows that from the interance to the end of the channel bend so the trend of suspended sediment concentration value are decreases. After the end of the channel bend started there is no more the angle influenced, the trend value of suspended sediment concentration are constant. As for the different radius, the value of suspended sediment concentration is still relatively the same and there is no change significantly. This shows that the relation or influence between the length of the radius of the bend with the value of the suspended sediment concentration is not visible
\end{abstract}

Keywords: concentration, angle of bend, radius of bend

\section{PENDAHULUAN}

Apabila debit sungai lebih besar dari debit bankfull, biasanaya akan terjadi penggerusan (scouring) pada sisi luar tikungan sungai dan menimbulkan tebing sungai longsor. Kejadian longsor sangat tergantung pada besarnya gerusan yang terjadi. Tidak semua daya gerus pada aliran menikung disebabkan oleh besarnya debit, karena masih banyak karakteristik aliran yang belum diketahui sebagai penyebabnya, seperti pengaruh besar sudut tikungan, panjang jari-jari tikungan dan pengaruh aspek rasio dari penampang aliran.

Konsentrasi sedimen suspensi pada suatu aliran sangat dipengaruhi parameter hidraulik aliran itu sendiri, seperti kecepatan aliran. Beberapa peneliti telah mengemukakan bahwa kecepatan aliran dapat mempengaruhi konsentrasi sedimen suspensi. Peneliti tersebut antara lain, Coleman (1986) dalam Kironoto (2007a), melakukan penelitian mengenai pengaruh sedimen suspensi terhadap distribusi kecepatan pada saluran terbuka, melaporkan bahwa adanya bed load mempengaruhi kandungan konsentrasi sedimen suspensi, yang juga mempengaruhi bentuk distribusi kecepatan dan distribusi konsentrasi sedimen suspensi. Ketebalan lapisan logaritmik dari profil kecepatan menurun sedangkan konsentrasi sedimen suspensi meningkat.

Sebagaimana dipaparkan diatas bahwa kecepatan aliran dapat mempengaruhi konsentrasi sedimen suspensi, sedangkan kecepatan aliran ssendiri sangat dipengaruhi oleh parameter hidrauliknya, seperti dimensi saluran, profil saluran, termasuk juga sudut tikungan dan jari-jari tikungan. Sehingga untuk mengetahui keterkaitan antara konsentrasi sedimen suspensi dengan parameter hidrauliknya maka dilakukan penelitian pengaruh sudut dan jari-jari tikungan terhadap konsentrasi sedimen 
suspensi arah transversal pada saluran menikung.

Dengan data pengukuran profil konsentrasi sedimen suspensi dan mengintegralkannya dengan batas antara kedalaman aliran dan kedalaman titik yang ditinjau, nilai konsentrasi sedimen suspensi rata-rata dapat diperoleh. Ekspresi persamaannya dapat ditulis.

$\bar{C}_{y}=\frac{1}{D-y} \int_{y}^{D} C . d y$

dengan:

D : kedalaman aliran (m)

$\mathrm{y}:$ posisi titik pengukuran dari dasar $(\mathrm{m})$

$\overline{C_{y}}$ : konsentrasi rata-rata vertikal (gr/liter)

Konsentrasi sedimen suspensi ratarata tampang saluran, $\bar{C}$ diperoleh dengan mengalikan konsentrasi sedimen suspensirata-rata vertikal, $\overline{C_{y}}$ dengan luasan (pias aliran) masing-masing, kemudian dibagi dengan total luasan tampang Graf, (1984) dalam Kironoto (2007b), seperti diberikan menurut persamaan sebagai berikut:

$\bar{C}=\frac{\overline{C_{y 1}} \cdot A_{1}+\ldots . .+\overline{C_{y n}} \cdot A_{n}}{A_{\text {Total }}}$

dengan: $\bar{C}=$ konsentrasi sedimen suspensi rata-rata tampang $(\mathrm{gr} / \mathrm{liter}), \overline{C_{y 1}} ; \overline{C_{y n}}=$ konsentrasi sedimen suspensi rata-rata vertikal pada pias aliran ke-1 dan ke- $n$ (gr/liter), $A_{1} ; A_{n}=$ luas tampang pias aliran ke-1 dan ken $\left(\mathrm{m}^{2}\right), A_{\text {Total }}=$ luas tampang aliran $\left(\mathrm{m}^{2}\right)$.

Untuk dapat melihat adanya keterkaitan antara konsentrasi sedimen suspensi dengan sudut dan jari-jari tikungan adalah membuat grafik hubungan antara nilai rasional parameter konsentrasi sedimen suspensi dengan nilai rasional parameter lebar saluran. Nilai rasional konsentrasi sedimen suspensi adalah pembagian nilai konsentrasi sedimen suspensi rata-rata kedalaman setiap tampang melintang dengan konsentrasi sedimen suspensi rata-rata tampang, $\overline{C_{y}} / \bar{C}$ Demikian juga untuk nilai rasional lebar saluran adalah dengan pembagian jarak lebar pengukuran di saluran, $z$ dengan lebar saluran yang sebenarnya di lapangan, $B$, sehingga nilai rasional lebar saluran, $z / B$

\section{METODOLOGI}

Metode yang diterapkan pada penelitian ini adalah eksperimen lapangan, yakni seluruh kegiatan pengukuran maupun pengambilan data dilaksanakan di lapangan. Peralatan yang digunakan untuk pengukuran konsentrasi sedimen suspensi adalah Opcon probe. Lokasi penelitian di laksanakan pada 4 (empat) lokasi saluran irigasi Mataram. Perinciannya adalah dua lokasi dengan sudut yang relatif sama tapi mempunyai jari-jari tikungan yang berbeda, dan dua jari-jari yang relatif sama tapi mempunyai sudut tikungan yang berbeda. Titik-titik pengukuran konsentrasi sedimen suspensi untuk setiap saluran menikung ditetapkan pada 5 (lima) cross section berada dalam busur saluran menikung (1 2,3,4 dan 5), seperti terlihat pada Gambar 1. 


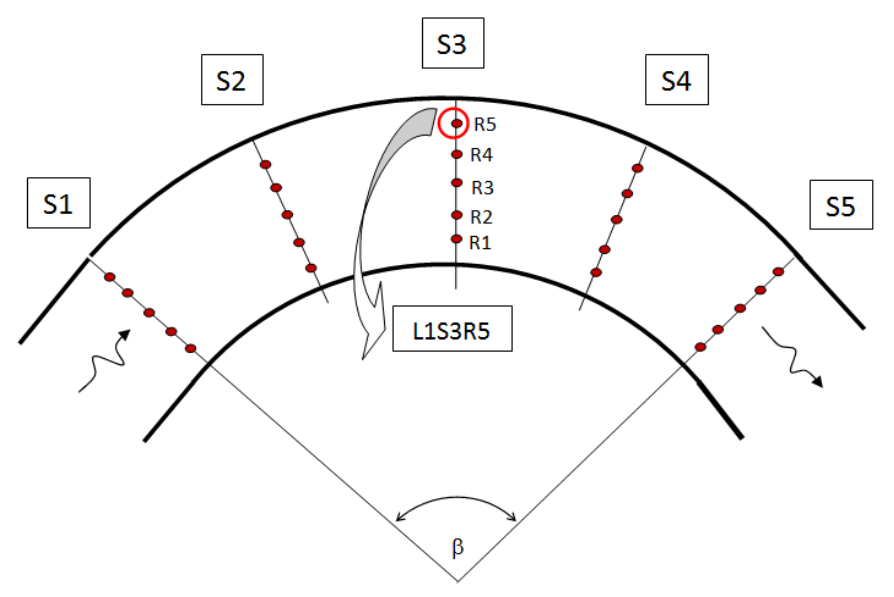

Gambar 1. Lokasi Pengukuran Cross Sections

Masing-masing cross section dibagi atau tegak lurus arah aliran. Seperti terlihat sebanyak 5 (lima) titik arah transversal pada Gambar 2.

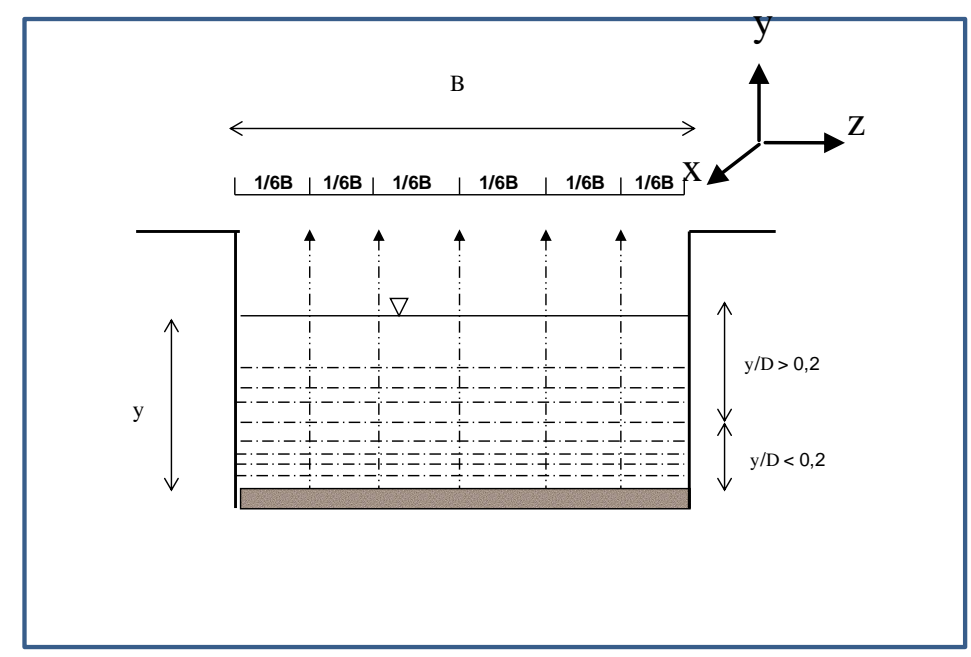

Gambar 2. Titik-titik pengukuran arah transversal dan vertikal

Setiap lima titik tersebut dibagi lagi untuk beberapa titik kedalaman untuk jumlah yang relatif cukup. Selanjutnya untuk setiap data yang diperoleh diberi notasi agar memudahkan dalam mengidentifikasnya. Jumlah titik-titik pengukuran dan pengambilan sampel pada kedalaman vertikal sewaktu waktu bisa berkurang atau bertambah sesuai situasi dan kondisi lapangan pada saat itu.

Selama pelaksanaan pengukuran di lapangan ketinggian muka air perlu selalu dikontrol yakni dengan cara menempatkan peil schaal dikedua sisi penampang saluran, kemudian diberi tanda.
Selanjutnya setiap perubahan ketinggian muka air dicatat dengan seksama. Hal ini dilakukan karena perubahan tinggi muka air akan berpengaruh terhadap besarnya debit aliran dan nilai aspek rasio dari penampang saluran tersebut.

\section{HASIL DAN PEMBAHASAN}

Data pengukuran diberi notasi/kode L, S dan R, yang merupakan singkatan dari location, $\mathrm{L}$, cross section, $\mathrm{S}$, dan radius (titik arah transversal), $\mathrm{R}$, diikuti dengan angka-angka yang menginformasikan urutan lokasi penelitian, potongan 
melintang dari hulu ke hilir saluran dan posisi pengukuran arah transversal dari outer bank ke inner bank. Misalnya, nama kode data pengukuran L1S3R1 yang mempunyai makna bahwa data pengukuran diperoleh di lokasi pertama, pada cross section ke tiga atau di tengah tikungan, dan pada posisi pertama dari outer bank ke inner bank atau posisi pertama arah transversal. Tabel 1. merupakan tampilan data utama hasil pengukuran pada 4 (empat) lokasi.

Tabel 1. Variabel pengukuran dan hitungan aliran menikung dengan sedimen suspensi

\begin{tabular}{|c|c|c|c|c|c|c|}
\hline Run & $\begin{array}{c}\mathrm{Q} \\
(\mathrm{m} 3 / \mathrm{dt})\end{array}$ & $\begin{array}{c}\mathrm{D} \\
(\mathrm{m}) \\
\end{array}$ & $\begin{array}{c}\mathrm{B} / \mathrm{D} \\
(-) \\
\end{array}$ & $\begin{array}{c}\bar{C} \\
(\mathrm{gr} / \mathrm{ltr})\end{array}$ & $\begin{array}{l}\text { Fr } \\
(-)\end{array}$ & $\begin{array}{c}\overline{C_{y}} \\
(\mathrm{gr} / \mathrm{ltr})\end{array}$ \\
\hline L1SIR1 & \multirow{5}{*}{1,816} & 0,71 & 5,92 & \multirow{5}{*}{1,637} & 0,221 & 1,715 \\
\hline L1SIR2 & & 0,73 & 5,75 & & 0,218 & 1,670 \\
\hline L1SIR3 & & 0,75 & 5,60 & & 0,215 & 1,614 \\
\hline L1SIR4 & & 0,77 & 5,45 & & 0,212 & 1,605 \\
\hline L1SIR5 & & 0,78 & 5,38 & & 0,211 & 1,588 \\
\hline L1S2R1 & \multirow{5}{*}{1,946} & 0,75 & 5,60 & \multirow{5}{*}{1,604} & 0,214 & 1,686 \\
\hline L1S2R2 & & 0,77 & 5,45 & & 0,212 & 1,648 \\
\hline L1S2R3 & & 0,80 & 5,25 & & 0,208 & 1,573 \\
\hline L1S2R4 & & 0,85 & 4,94 & & 0,201 & 1,571 \\
\hline L1S2R5 & & 0,85 & 4,94 & & 0,201 & 1,558 \\
\hline L1S3R1 & \multirow{5}{*}{1,831} & 0,70 & 6,00 & \multirow{5}{*}{1,591} & 0,212 & 1,662 \\
\hline L1S3R2 & & 0,78 & 5,38 & & 0,201 & 1,623 \\
\hline L1S3R3 & & 0,80 & 5,25 & & 0,198 & 1,581 \\
\hline L1S3R4 & & 0,83 & 5,06 & & 0,195 & 1,566 \\
\hline L1S3R5 & & 0,85 & 4,94 & & 0,192 & 1,540 \\
\hline L1S4R1 & \multirow{5}{*}{1,724} & 0,64 & 6,56 & \multirow{5}{*}{1,565} & 0,216 & 1,631 \\
\hline L1S4R2 & & 0,73 & 5,75 & & 0,202 & 1,600 \\
\hline L1S4R3 & & 0,77 & 5,45 & & 0,197 & 1,557 \\
\hline L1S4R4 & & 0,82 & 5,12 & & 0,190 & 1,545 \\
\hline L1S4R5 & & 0,84 & 5,00 & & 0,188 & 1,511 \\
\hline \multirow{2}{*}{ Run } & Q & $\mathrm{D}$ & $\mathrm{B} / \mathrm{D}$ & $\bar{C}$ & $\mathrm{Fr}$ & $\overline{C_{y}}$ \\
\hline & $(\mathrm{m} 3 / \mathrm{dt})$ & (m) & $(-)$ & (gr/ltr) & $(-)$ & (gr/ltr) \\
\hline L1S5R1 & \multirow{5}{*}{1,730} & 0,65 & 6,46 & \multirow{5}{*}{1,539} & 0,218 & 1,591 \\
\hline L1S5R2 & & 0,70 & 6,00 & & 0,210 & 1,572 \\
\hline L1S5R3 & & 0,75 & 5,60 & & 0,203 & 1,531 \\
\hline L1S5R4 & & 0,80 & 5,25 & & 0,197 & 1,538 \\
\hline L1S5R5 & & 0,84 & 5,00 & & 0,192 & 1,481 \\
\hline L2SIR1 & \multirow{5}{*}{1,088} & 0,68 & 6,18 & \multirow{5}{*}{1,254} & 0,134 & 1,375 \\
\hline L2SIR2 & & 0,74 & 5,68 & & 0,128 & 1,299 \\
\hline L2SIR3 & & 0,78 & 5,38 & & 0,125 & 1,246 \\
\hline L2SIR4 & & 0,79 & 5,32 & & 0,124 & 1,197 \\
\hline L2SIR5 & & 0,81 & 5,19 & & 0,123 & 1,176 \\
\hline L2S2R1 & & 0,68 & 6,18 & & 0,150 & 1,326 \\
\hline L2S2R2 & & 0,74 & 5,68 & & 0,144 & 1,263 \\
\hline L2S2R3 & 1,218 & 0,78 & 5,38 & 1,220 & 0,140 & 1,221 \\
\hline
\end{tabular}




\begin{tabular}{|c|c|c|c|c|c|c|}
\hline L2S2R 4 & & 0,80 & 5,25 & & 0,138 & 1,167 \\
\hline L2S2R5 & & 0,83 & 5,06 & & 0,136 & 1,147 \\
\hline L2S3R1 & \multirow{5}{*}{1,320} & 0,65 & 6,46 & \multirow{5}{*}{1,196} & 0,166 & 1,310 \\
\hline L2S3R2 & & 0,70 & 6,00 & & 0,160 & 1,257 \\
\hline L2S3R3 & & 0,78 & 5,38 & & 0,151 & 1,195 \\
\hline L2S3R4 & & 0,82 & 5,12 & & 0,148 & 1,138 \\
\hline L2S3R5 & & 0,85 & 4,94 & & 0,145 & 1,117 \\
\hline L2S4R1 & \multirow{5}{*}{1,448} & 0,65 & 6,46 & \multirow{5}{*}{1,162} & 0,182 & 1,247 \\
\hline L2S4R2 & & 0,67 & 6,27 & & 0,179 & 1,209 \\
\hline L2S4R3 & & 0,70 & 6,00 & & 0,175 & 1,174 \\
\hline L2S4R4 & & 0,75 & 5,60 & & 0,169 & 1,108 \\
\hline L2S4R5 & & 0,80 & 5,25 & & 0,164 & 1,096 \\
\hline L2S5R1 & \multirow{5}{*}{1,627} & 0,65 & 6,46 & \multirow{5}{*}{1,123} & 0,205 & 1,186 \\
\hline L2S5R2 & & 0,70 & 6,00 & & 0,197 & 1,157 \\
\hline L2S5R3 & & 0,75 & 5,60 & & 0,190 & 1,146 \\
\hline L2S5R4 & & 0,80 & 5,25 & & 0,184 & 1,077 \\
\hline L2S5R5 & & 0,85 & 4,94 & & 0,179 & 1,070 \\
\hline L3SIR1 & \multirow{5}{*}{1,580} & 0,75 & 5,60 & \multirow{5}{*}{1,264} & 0,160 & 1,374 \\
\hline L3SIR2 & & 0,90 & 4,67 & & 0,146 & 1,365 \\
\hline L3SIR3 & & 0,91 & 4,62 & & 0,146 & 1,253 \\
\hline L3SIR4 & & 0,92 & 4,57 & & 0,145 & 1,203 \\
\hline L3SIR5 & & 0,93 & 4,52 & & 0,144 & 1,154 \\
\hline L3S2R1 & \multirow{5}{*}{1,448} & 0,72 & 5,83 & \multirow{5}{*}{1,214} & 0,150 & 1,311 \\
\hline L3S2R2 & & 0,92 & 4,57 & & 0,133 & 1,279 \\
\hline L3S2R3 & & 0,93 & 4,52 & & 0,132 & 1,215 \\
\hline L3S2R4 & & 0,94 & 4,47 & & 0,131 & 1,171 \\
\hline L3S2R5 & & 0,95 & 4,42 & & 0,131 & 1,125 \\
\hline Run & Q & $\mathrm{D}$ & $\mathrm{B} / \mathrm{D}$ & C & $\mathrm{Fr}$ & $C_{y}$ \\
\hline
\end{tabular}

\begin{tabular}{|c|c|c|c|c|c|c|}
\hline & $(\mathrm{m} 3 / \mathrm{dt})$ & (m) & $(-)$ & (gr/ltr) & $(-)$ & (gr/ltr) \\
\hline L3S3R1 & & 0,60 & 7,00 & & 0,154 & 1,251 \\
\hline L3S3R2 & & 0,75 & 5,60 & & 0,137 & 1,207 \\
\hline L3S3R3 & 1,353 & 0,90 & 4,67 & 1,160 & 0,125 & 1,178 \\
\hline L3S3R4 & & 1,00 & 4,20 & & 0,119 & 1,132 \\
\hline L3S3R5 & & 1,06 & 3,96 & & 0,116 & 1,087 \\
\hline L3S4R1 & & 0,65 & 6,46 & & 0,141 & 1,191 \\
\hline L3S4R2 & & 0,75 & 5,60 & & 0,131 & 1,150 \\
\hline L3S4R3 & 1,292 & 0,85 & 4,94 & 1,112 & 0,123 & 1,116 \\
\hline L3S4R4 & & 1,00 & 4,20 & & 0,114 & 1,085 \\
\hline L3S4R5 & & 1,05 & 4,00 & & 0,111 & 1,059 \\
\hline L3S5R1 & & 0,65 & 6,46 & & 0,132 & 1,134 \\
\hline L3S5R2 & & 0,77 & 5,45 & & 0,121 & 1,092 \\
\hline L3S5R3 & 1,211 & 0,82 & 5,12 & 1,066 & 0,118 & 1,053 \\
\hline L3S5R4 & & 0,88 & 4,77 & & 0,113 & 1,046 \\
\hline L3S5R5 & & 1,02 & 4,12 & & 0,105 & 1,032 \\
\hline L4SIR1 & & 0,70 & 6,00 & & 0,188 & 1,799 \\
\hline L4SIR2 & & 0,73 & 5,75 & & 0,184 & 1,775 \\
\hline
\end{tabular}




\begin{tabular}{lllllll} 
L4SIR3 & 1,560 & 0,76 & 5,53 & 1,733 & 0,181 & 1,750 \\
L4SIR4 & & 0,78 & 5,38 & & 0,178 & 1,703 \\
L4SIR5 & & 0,81 & 5,19 & & 0,175 & 1,653 \\
\hline L4S2R1 & & 0,68 & 6,18 & & 0,183 & 1,657 \\
L4S2R2 & & 0,70 & 6,00 & & 0,180 & 1,692 \\
L4S2R3 & 1,496 & 0,75 & 5,60 & 1,640 & 0,174 & 1,654 \\
L4S2R4 & & 0,78 & 5,38 & & 0,171 & 1,623 \\
L4S2R5 & & 0,83 & 5,06 & & 0,166 & 1,588 \\
\hline L4S3R1 & & 0,57 & 7,37 & & 0,216 & 1,719 \\
L4S3R2 & & 0,73 & 5,75 & & 0,191 & 1,606 \\
L4S3R3 & 1,617 & 0,75 & 5,60 & 1,580 & 0,188 & 1,556 \\
L4S3R4 & & 0,85 & 4,94 & & 0,177 & 1,537 \\
L4S3R5 & & 0,87 & 4,83 & & 0,175 & 1,524 \\
\hline L4S4R1 & & 0,65 & 6,46 & & 0,180 & 1,625 \\
L4S4R2 & & 0,68 & 6,18 & & 0,176 & 1,624 \\
L4S4R3 & 1,441 & 0,70 & 6,00 & 1,581 & 0,174 & 1,581 \\
L4S4R4 & & 0,75 & 5,60 & & 0,168 & 1,558 \\
L4S4R5 & & 0,82 & 5,12 & & 0,161 & 1,531 \\
\hline L4S5R1 & & 0,68 & 6,18 & & 0,188 & 1,675 \\
L4S5R2 & & 0,77 & 5,45 & & 0,177 & 1,638 \\
L4S5R3 & 1,536 & 0,81 & 5,19 & 1,600 & 0,172 & 1,601 \\
L4S5R4 & & 0,83 & 5,06 & & 0,170 & 1,568 \\
L4S5R5 & & 0,85 & 4,94 & & 0,168 & 1,533 \\
\hline
\end{tabular}

\section{Keterangan:}

$Q=$ debit aliran terukur; $D=$ kedalaman aliran; $B / D=$ aspect ratio; $B=$ lebar saluran $(B 1=4,22$ m, B2=4,18 m, B3=4,12 m, B4=4,07 m), $F r=$ $U /(g D)^{0.5} ; \overline{C_{y}}=$ konsentrasi sedimen suspensi rata-rata kedalaman, $g=$ percepatan gravitasi; $\bar{C}=$ konsentrasi sedimen suspensi rata-rata tampang.

Keterkaitan antara nilai konsentrasi sedimen suspensi dengan sudut tikungan dapat diketahui dengan membandingkan grafik hubungan nilai, $\overline{C_{y}} / \bar{C}$ dengan nilai, $z / B$ pada dua lokasi yang mempunyai besar sudut tikungan yang berbeda tetapi mempunyai panjang jari-jari tikungan relatif sama. Keterkaitan antara nilai konsentrasi sedimen suspensi dengan panjang jari-jari tikungan dapat diketahui dengan membandingkan grafik hubungan nilai, $\overline{C_{y}} / \bar{C}$ dengan nilai, $z / B$ pada dua lokasi yang mempunyai panjang jari-jari tikungan yang berbeda tetapi mempunyai besar sudut tikungan yang relatif sama. Lokasi yang mempunyai besar sudut tikungan yang berbeda tetapi mempunyai panjang jari-jari tikungan relatif sama adalah lokasi 3 (L3, $\alpha=30^{\circ}$ dan $r=60 \mathrm{~m}$ ) dengan lokasi 4 ( L4 $\alpha=50^{\circ}$ dan $r=59 \mathrm{~m}$ ). Lokasi yang mempunyai jari-jari tikungan yang berbeda tetapi mempunyai besar sudut tikungan relatif sama adalah lokasi 1 (L1 $\alpha=55^{\circ}$ dan $\mathrm{r}=21 \mathrm{~m}$ ) dengan lokasi 2 (L2 $\alpha=57^{\circ}$ dan $\mathrm{r}=50 \mathrm{~m}$ ).

Gambar 3.a,b,c,d,e menunjukkan hubungan antara konsentrasi sedimen suspensi dan sudut tikungan di lokasi 3 dan lokasi 4 


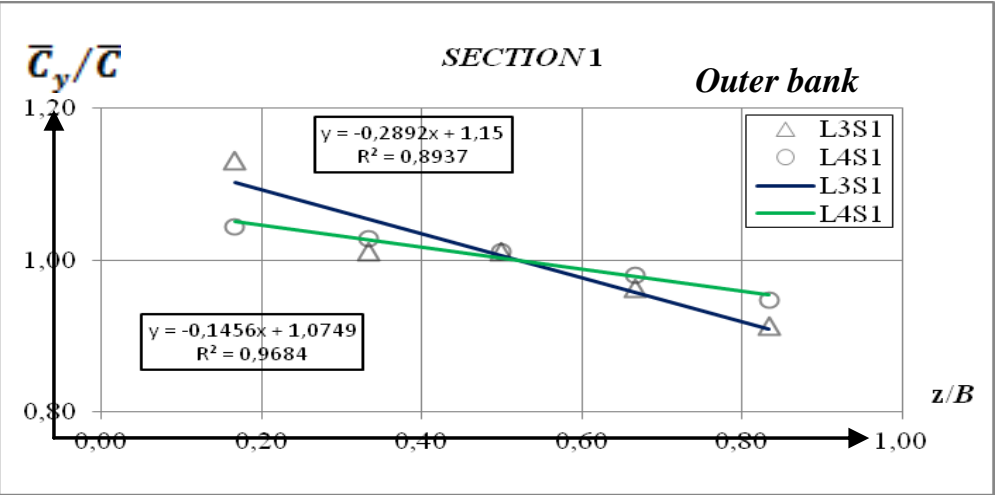

Gambar 3a. Super posisi nilai $\bar{C}_{y} / \bar{C}$ dengan $z / B$ section 1 di lokasi 3 dan 4

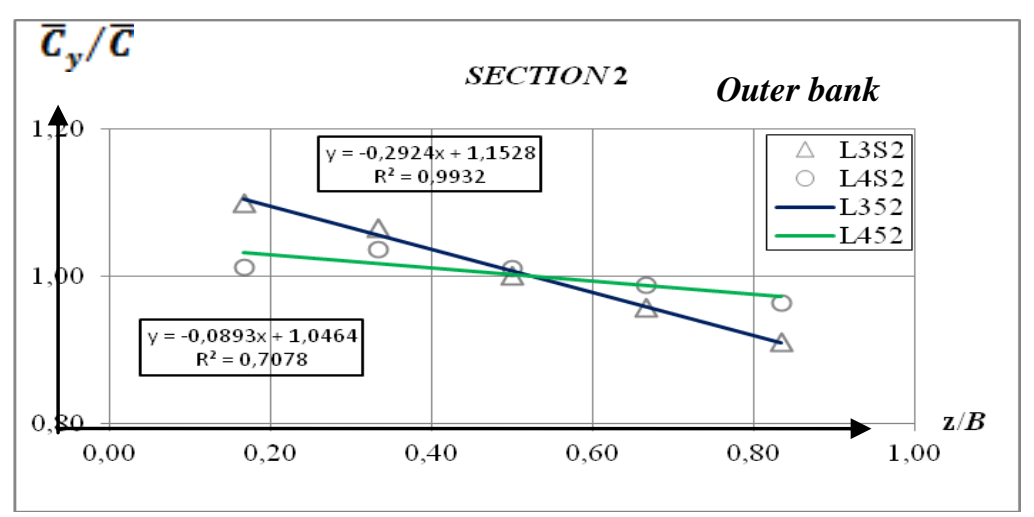

Gambar 3b. Super posisi nilai $\bar{C}_{y} / \bar{C}$ dengan $z / B$ section 2 di lokasi 3 dan 4

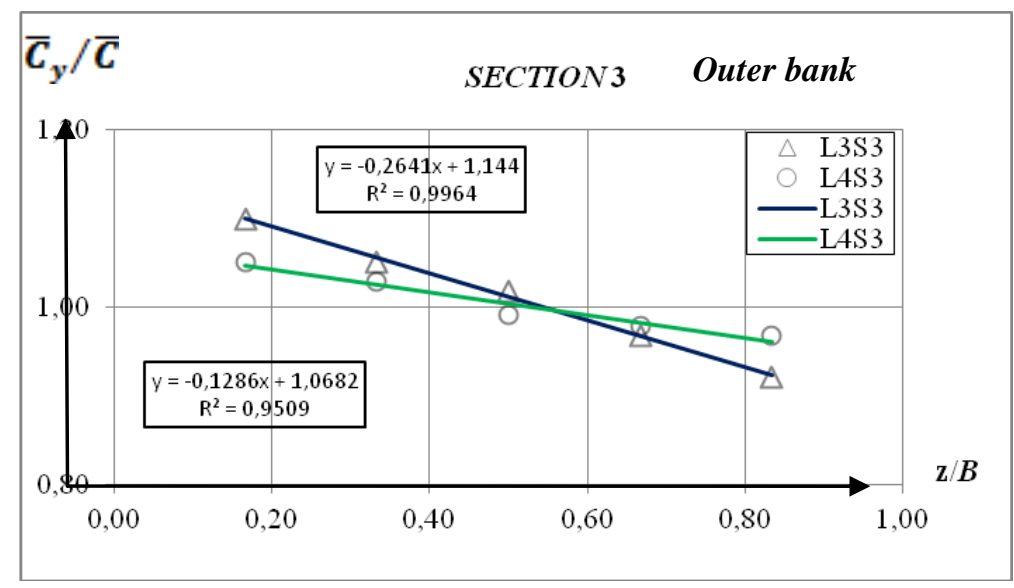

Gambar 3c. Super posisi nilai $\bar{C}_{y} / \bar{C}$ dengan $z / B$ section 3 di lokasi 3 dan 4

$$
\overline{\boldsymbol{C}}_{\boldsymbol{y}} / \overline{\boldsymbol{C}}
$$




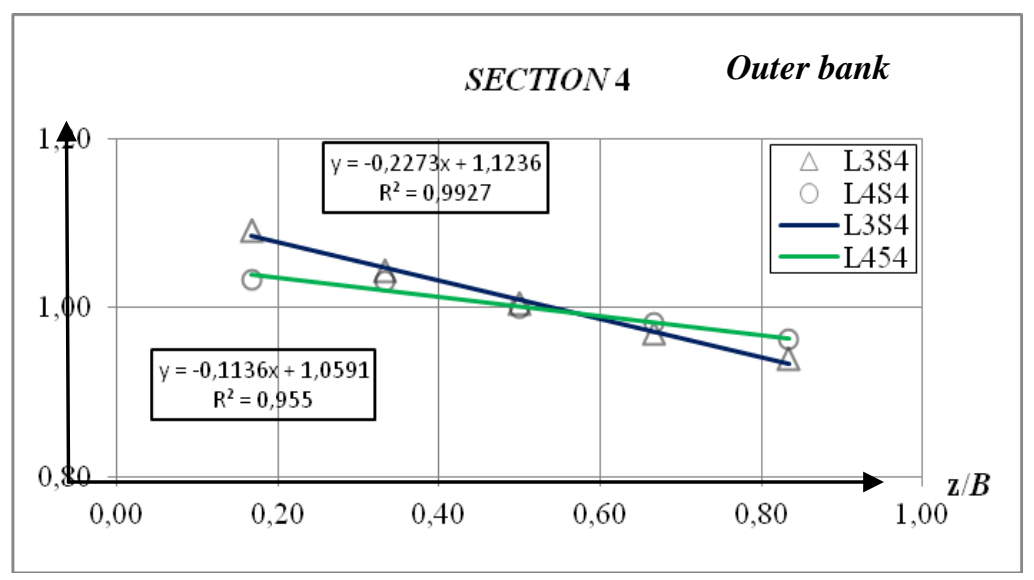

Gambar 3d. Super posisi nilai $\overline{\boldsymbol{C}}_{\boldsymbol{y}} / \overline{\boldsymbol{C}}$ dengan $z / B$ section 4 di lokasi 3 dan 4

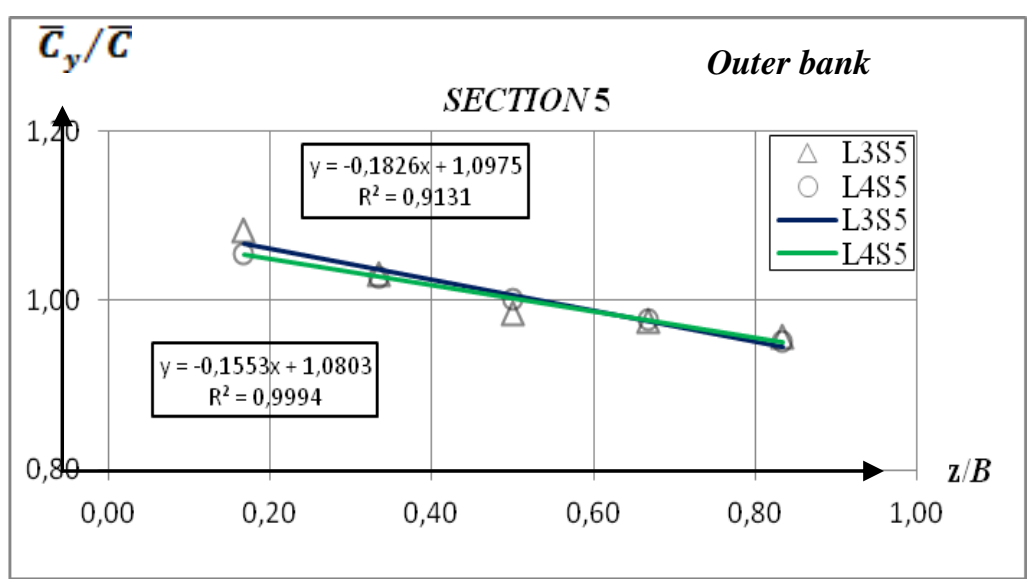

Gambar 3e. Super posisi nilai $\bar{C}_{y} / \bar{C}$ dengan $z / B$ section 5 di lokasi 3 dan 4

Hubungan antara distribusi konsentrasi sedimen suspensi dengan besar sudut tikungan ditunjukan oleh Gambar 3.a.b.c.d.e, untuk 5 (lima) tampang arah transversal dari inner bank ke outer bank. Dapat dilihat bahwa pada awal tikungan sampai diakhir tikungan, trend nilai konsentrasi sedimen suspensi semakin turun. Setelah diakhir tikungan mulai tidak ada pengaruh besar sudut tikungan, yakni trend nilai distribusi konsentrasi sedimen suspensi konstan.

Gambar 4.a,b,c,d,e menunjukkan hubungan antara konsentrasi sedimen suspensi dan jari-jari tikungan di lokasi 1 dan lokasi 2 


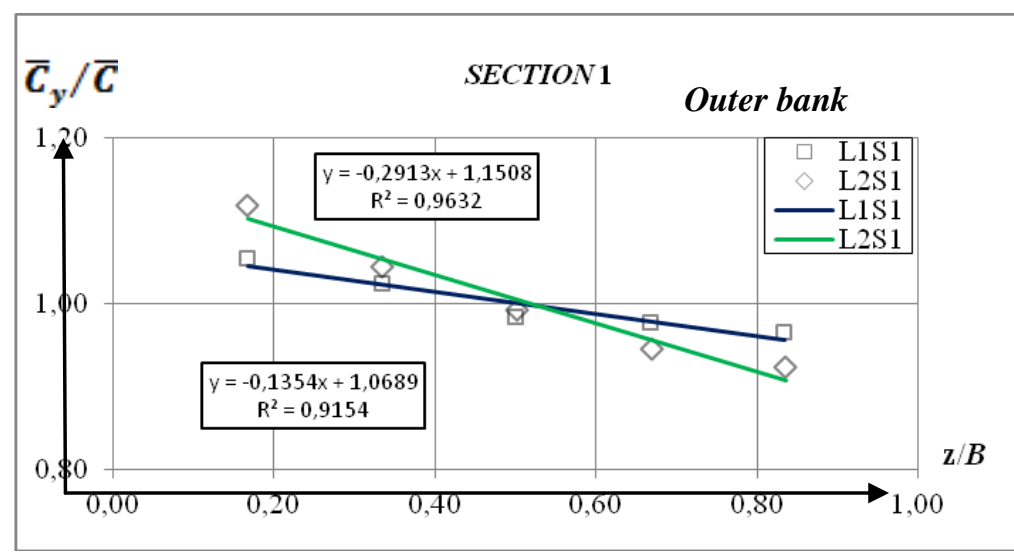

Gambar 4a. Super posisi nilai $\bar{C} / C$ dengan $z / B$ section 1 di lokasi 1 dan 2

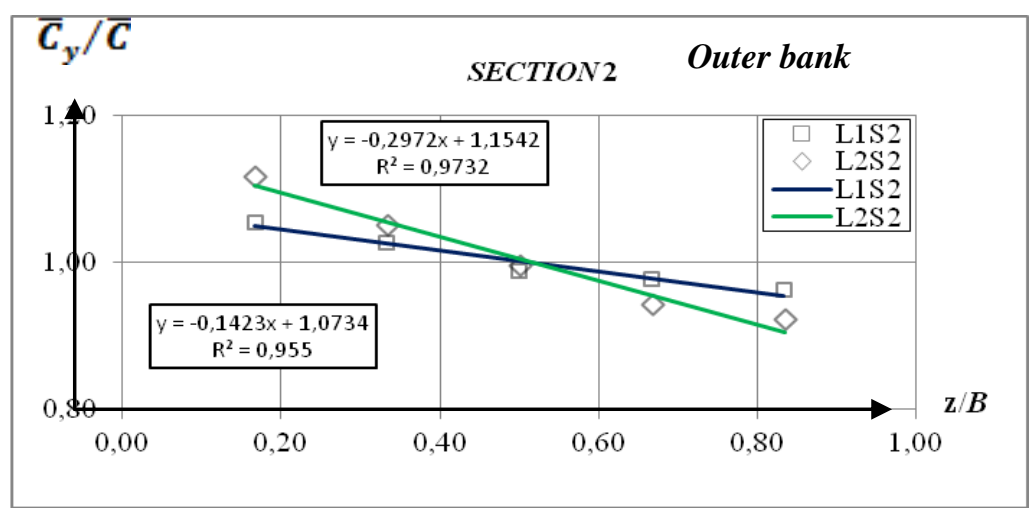

Gambar 4b. Super posisi nilai $\overline{C_{y}} / \bar{C}$ dengan $z / B$ section 2 di lokasi 1 dan 2

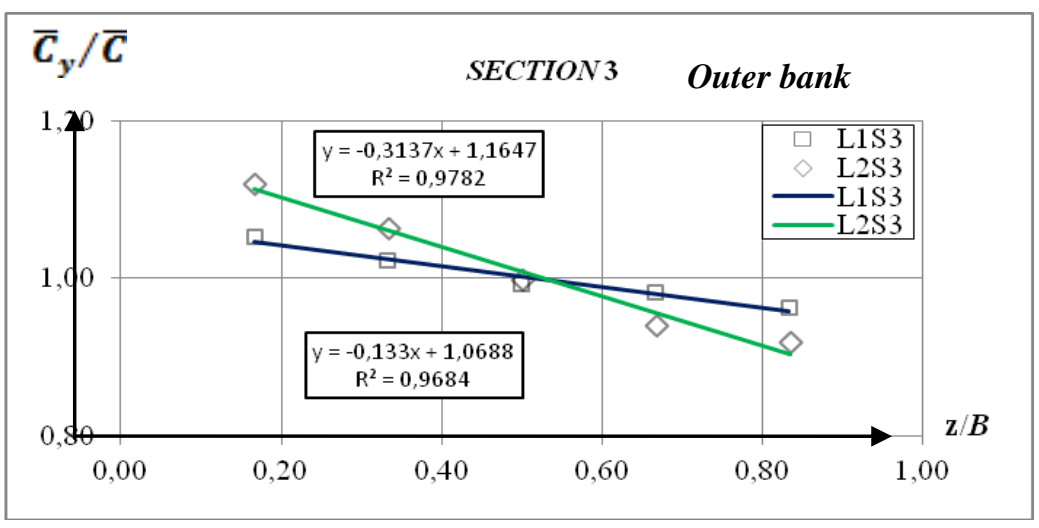

Gambar 4c. Super posisi nilai $\bar{C}_{y} / \bar{C}$ dengan $z / B$ section 3 di lokasi 1 dan 2 


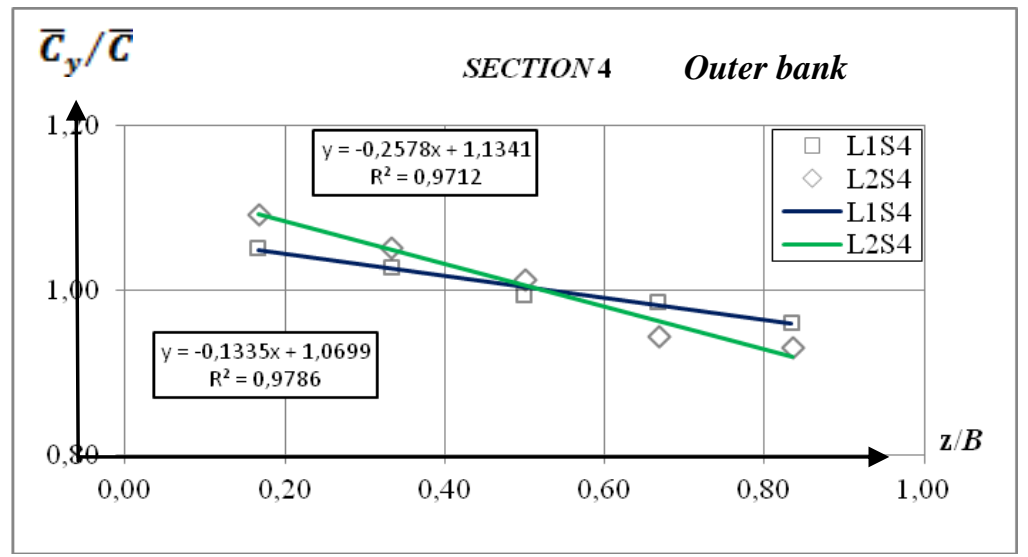

Gambar 4d. Super posisi nilai $\bar{C}_{y} / \bar{C}$ dengan $z / B$ section 4 di lokasi 1 dan 2

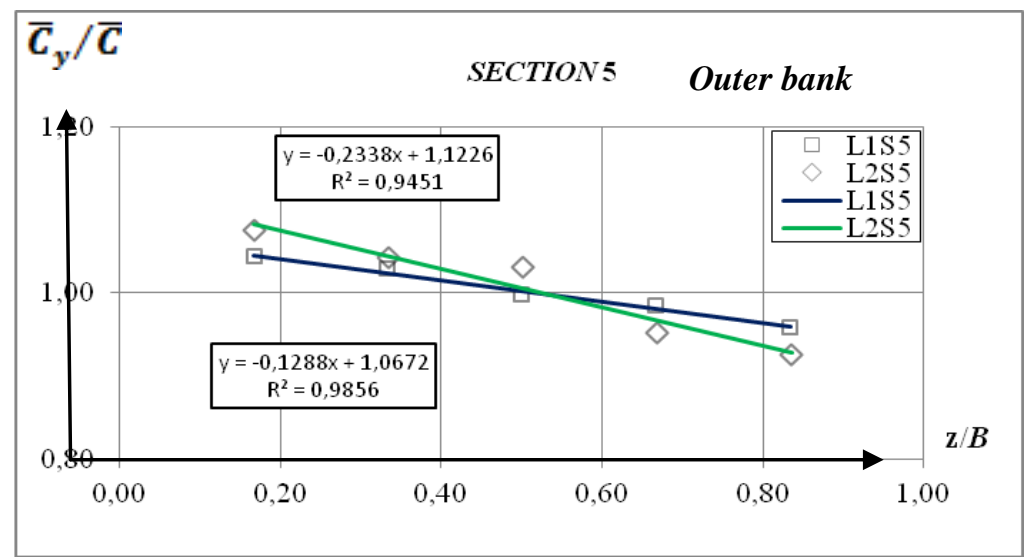

Gambar 4e. Super posisi nilai $\bar{C}_{y} / \bar{C}$ dengn $z / B$ section 5 di lokasi 1 dan 2

Keterkaitan distribusi konsentrasi sedimen suspensi dengan panjang jari-jari tikungan ditunjukan oleh Gambar 4.a,b,c,d, e, untuk 5 (lima) tampang arah transversal dari inner bank ke outer bank. Terlihat bahwa pada dari awal tikungan sampai di akhir tikungan trend nilai grafik masih relatif sama dan tidak ada perubahan yang signifikan. Hal ini menunjukan bahwa keterkaitan atau pengaruh antara panjang jari-jari tikungan dengan nilai distribusi konsentrasi sedimen suspensi tidak terlihat.

\section{SIMPULAN}

Keterkaitan nilai distribusi konsentrasi sedimen suspensi dengan besar sudut bahwa pada awal tikungan sampai di akhir tikungan, trend nilai menunjukan semakin besar sudut tikungan semakin mengecil konsentrasi sedimen suspensi. Setelah di akhir tikungan mulai tidak ada pengaruh besar sudut tikungan, yakni trend nilai distribusi konsentrasi sedimen suspensi konstan. Hal ini menunjukan bahwa ada keterkaitan atau pengaruh antara panjang jari-jari besar sudut tikungan dengan nilai distribusi konsentrasi sedimen suspensi

Keterkaitan nilai distribusi konsentrasi sedimen suspensi dengan panjang jari-jari tikungan adalah pada dari awal tikungan sampai di akhir tikungan trend nilai masih relatif sama dan tidak ada perubahan yang signifikan. Hal ini menunjukan bahwa keterkaitan atau pengaruh antara panjang jari-jari tikungan dengan nilai distribusi konsentrasi sedimen suspensi tidak signifikan. 


\section{SARAN}

Kajian pengaruh sudut dan jari-jari tikungan terhadap konsentrasi sedimen suspensi arah transversal pada saluran menikung, masih sangat luas untuk dikembangkan lagi terutama apabila dikomparasikan antara hasil penelitian di laboratorium dengan hasil penelitian di lapangan. Masih banyak parameter aliran sedimen suspensi yang perlu diselidiki seperti untuk tinjauan dimensi saluran yang berbeda.

\section{UCAPAN TERIMA KASIH}

Ucapan terima kasih disampaikan kepada Balai Sungai Serayu-Opak yang memberi ijin melakukan penelitian di Saluran Irigasi Mataram, Lembaga Penelitian dan Pengabdian Kepada Masyarakat (LPPM) Universitas Gadjah Mada, yang telah memberikan support dana penelitian Pascasarjana Tahun Anggaran 2014, selanjutnya kepada rekan-rekan mahasiswa S2 Teknik Sipil banyak membantu sehingga tulisan ini dapat terwujud.

\section{DAFTAR PUSTAKA}

Muharis C, Kironoto B.A. Yulistiyanto B, dan Istiarto., 2015. Distribusi Konsentrasi Sedimen Suspensi Arah Transversal pada Saluran Menikung, disajikan pada Seminar Nasional TEKNIK SIPIL XI, 28 Januari 2015, Surabaya.

Kironoto, B.A., 2007a. Kajian Lokasi Pengambilan Sampel Sedimen Suspensi Arah Transversal Terhadap Nilai Konsentrasi Sedimen Suspensi Rata-rata Tampang, Dinamika Teknik Sipil Volume 7 No.2, pg 101 - 108, Yogyakarta

Kironoto, B.A., 2007b. Karakteristik Aliran Tidak Seragam dengan Sedimen Suspensi pada Saluran Terbuka, Dinamika Teknik Sipil Volume 7 No.2, pg 154 - 162, Yogyakarta 